\title{
Comércio internacional e meio ambiente e da perspectiva do Estado constitucional cooperativo
}

\author{
Vladmir Oliveira da Silveira \\ vladmir@aus.com.br
}

Doutor em Direito pela PUC-SP,

Professor da PUC-SP, Professor do

Programa de Mestrado e Doutorado da FADISP e Presidente do CONPEDI.

\section{Érica Barbosa Joslin}

ericajoslin@hotmail.com

Mestranda em Direito pela PUC-SP e PósGraduada Lato Sensu em Direito Público e Privado pela FDDJ.

Recebimento do artigo: 23/09/2009 Aprovado em: 10/12/2009

\section{Resumo}

Este artigo pretende apresentar uma reflexão jurídica sobre a relação entre comércio internacional e meio ambiente, da perspectiva do Estado constitucional cooperativo, do princípio da solidariedade e o direito ao desenvolvimento sustentável. Sob tal ótica são apresentados os princípios e normas da OMC com destaque para a exceção ambiental ao livre comércio e sua respectiva aceitação como medida justificável de tutela da vida e da saúde de todos. Por fim trazemos à baila o caso da gasolina dos Estados Unidos e dos pneus reformados: Brasil versus UE, justamente por suas implicações no meio ambiente e no direito ao desenvolvimento dos Estados, especialmente considerando as peculiaridades do bloco regional do Cone Sul (Mercosul) em relação aos compromissos econômicos assumidos na OMC. Dentro dessa perspectiva, também completaremos nosso objetivo ao abordarmos as relações do Mercosul, intra-bloco e com terceiros países.

\section{Palavras-chave}

Comércio Internacional. Meio Ambiente. Estado Constitucional Cooperativo. Solidariedade e Desenvolvimento Sustentável. 


\title{
International trade and environment under the perspective of the cooperative constitutional state
}

\author{
Vladmir Oliveira da Silveira
}

Érica Barbosa Joslin

\section{Abstract}

This article aims at presenting a legal reflection on the relationship between international trade and environment, from the perspective of the Cooperative Constitutional State, solidarityprinciples and the right to sustainable development. From such a perspective, the principles and rules of the WTO are presented, with emphasis on the environmental exception to free trade and its acceptance as a justifiable measure of life tutelage and health for all. Finally, we come up with the event of gasoline in the United States and retread tyres: Brazil vs. EU, precisely because of its implications on the environment and on the right of the development of States, especially considering the peculiarities of the Southern Cone regional bloc in relation to the economic commitments made in the WTO. Within this perspective, we will also complete our goal as we address the relationship of Mercosul, intra-bloc and with other countries.

\section{Key words}

International Trade. Environment. Cooperative Constitutional State. Solidarity and Sustainable Development. 


\section{Sumário}

Introdução.

1 Histórico.

2 Objetivos, Princípios e Normas da OMC.

2.1 Acesso a Mercados.

2.2 Princípio da Solidariedade.

2.3 Tratamento Nacional.

3 Comércio Internacional e Meio Ambiente.

4 Casos Práticos.

4.1 Caso das normas dos Estados Unidos para a gasolina reformulada e convencional.

4.2 Caso da Proibição do Brasil de importação de pneumáticos reformados provenientes da União Européia no Sistema da OMC.

5 Mercosul: relações intrabloco e com terceiros países.

Considerações Finais.

Referências Bibliográficas.

\section{Introdução}

O presente trabalho consiste numa análise reflexiva acerca de um tema extremamente relevante e em voga no momento, qual seja, a relação entre o comércio internacional e a tutela ao meio ambiente.

Nesse sentido, iniciaremos expondo os objetivos da Organização Mundial do Comércio, assim como procuraremos apontar dentre esses objetivos aqueles que visam a uma harmonização entre comércio e meio ambiente, na perspectiva do Estado Constitucional Cooperativo. Da mesma maneira buscaremos apontar os princípios que norteiam a OMC, como o comércio sem discriminação, o acesso a mercados e o tratamento nacional para, enfim, correlacionarmos tais princípios com a importantissima questão da proteção do meio ambiente por intermédio de um desenvolvimento sustentável. Ademais, não nos furtaremos a um estudo mais 
minucioso sobre as barreiras não tarifárias ambientais e a caracterização ou não do dumping ecológico diante de casos concretos, escolhidos para facilitar uma maior visualização dos temas teóricos

Objetivamos ainda estudar a perspectiva integrativa entre comércio internacional e meio ambiente, que se tornou indissociável diante dos chamados direitos humanos de terceira geração (direitos de solidariedade), consistente na racionalização do uso dos meios ambientais em busca do desenvolvimento econômico associado a uma melhor qualidade de vida das presentes e futuras gerações.

Por fim, apresentaremos dois casos levados ao Órgão de Solução de Controvérsias da OMC envolvendo o tema "proteção ao meio ambiente", quais sejam: (i) Estados Unidos: Normas para gasolina reformulada e convencional e (ii) Proibição do Brasil de importação de pneumáticos reformados provenientes da União Européia no sistema da OMC, relacionando-os com o tema central deste estudo, com o objetivo de demonstrar a complexidade do tema, bem como a necessidade de uma nova teoria geral do Estado que aproxime especialmente o direito internacional público e o direito constitucional, haja vista os interesses difusos, comunitários e universais, além do atual paradigma de solidariedade internacional, cunhado internacionalmente a partir da criação da Organização das Nações Unidas e a conseqüente Declaração Universal dos Direitos Humanos, de 1948.

\section{Histórico}

Depois da Segunda Guerra Mundial (1939-1945), líderes das então potências mundiais se reuniram em Bretton Woods a fim de encontrar uma solução para a difícil situação do pós-guerra. Nesse encontro se criou o Banco Mundial (BIRD) e o Fundo Monetário Internacional (FMI), instituições econômicas voltadas para a reconstrução das nações devastadas pela guerra. Mais tarde, em 1947, foi celebrado também o Acordo Geral de Tarifas e Comércio (GATT), cujo objetivo era a retomada do crescimento econômico mundial pela liberalização do comércio, principalmente por meio da redução de tarifas alfandegárias.

O GATT, precursor da OMC, foi desenvolvido em rodadas de negociações, sendo que a primeira foi a Rodada Genebra (1947). Da primeira à quinta rodada, também em Genebra (1960-1961), o tema tratado foi basicamente a redução tarifária. Na sexta rodada (Rodada Kennedy, 1964-1967), além do tema recorrente, foram discutidos outros, como as medidas antidumping. Já a sétima rodada (Rodada Tóquio, 1973-1979) teve como novidade as medidas não tarifárias e os acordos de base, ou seja, as medidas de liberalização do comércio internacional, pautadas no princípio 
da não discriminação e concretizadas pelos instrumentos do acesso a mercados, cláusula da nação mais favorecida, e tratamento nacional, conforme veremos mais adiante. A oitava rodada (Rodada Uruguai, 1986-1994), apresentou-se como multitemática, abordando uma série de questões do comércio internacional, tais como, (i) a redução tarifária, (ii) as medidas não-tarifárias, (iii) os serviços, (iv) a propriedade intelectual, (vi) a resolução de disputas, (vii) os têxteis, (viii) a agricultura, e (ix) a criação da OMC. ${ }^{1}$

A Rodada Uruguai representou a mais ampla negociação comercial até então conhecida no âmbito do GATT-47, envolvendo 123 (cento e vinte e três) países e quase todos os aspetos do comércio mundial de bens, serviços e propriedade intelectual, além da fundamental criação de uma organismo internacional que abrangesse todos esses temas, qual seja, a OMC (Organização Mundial do Comércio).

Todos os países contratantes do GATT-47 puderam fazer parte da OMC como membros originários no dia de sua entrada em vigor, isto é, em $1^{\circ}$ de janeiro de 1995. Observe-se, todavia, que esse dispositivo também se aplica à Comunidade Européia embora ela não fosse, na época, parte integrante do GATT- $47^{2}$. A única restrição a essa regra é a necessidade de ratificação da Ata Final da Rodada Uruguai pelos respectivos países. Já os países que não fizessem parte do GAT'T-47, mas desejassem integrar a OMC, teriam que negociar sua entrada para que pudessem integrá-la como membro originário. Por fim, após a entrada em vigor da OMC, todo e qualquer país que queira fazer parte dessa organização deverá negociar os termos de sua adesão.

Historicamente, embora o Acordo Geral sobre Tarifas e Comércio (GATT-47) já ressaltasse a importância do meio ambiente pela criação do Grupo sobre Medidas Ambientais de 1948 (Group on Environmental Measures and International Trade - EMIT Group), é somente na década de 70 que se verifica efetivamente uma maior preocupação com o tema, haja vista a adoção de medidas ambientais e suas implicações no comércio.

\footnotetext{
1 Grandes foram os avanços alcançados na Rodada Uruguai, especialmente por parte dos países desenvolvidos e na área de produtos manufaturados. Todavia, os produtos têxteis e os agrícolas, de interesse dos países em desenvolvimento, foram desde logo sujeitos a regras especiais e não foram liberalizados. Somente em 1995, com a criação da OMC, é iniciada a liberalização da agricultura e dos têxteis; porém ainda há muito que evoluir, especialmente no que tange à eliminação das barreiras tarifarias e à concessão de subsídios à exportação por parte dos países desenvolvidos. A expectativa era que se chegasse a um consenso quando da conclusão da Rodada Doha, prevista para o fim de 2008. Entretanto, diante de um novo impasse entre países desenvolvidos e não desenvolvidos/em desenvolvimento, até o momento não ocorreu avanço significativo.

2 Art. XI do Acordo Constitutivo da Organização Mundial do Comércio.
} 
Na Rodada Uruguai (1986-1994), o EMIT Group transforma-se no Comitê sobre Comércio e Meio Ambiente (Commitee on Environment and Trade - CET). A partir daí, o acesso a mercados e os temas comuns às agendas de comércio e meio ambiente, em âmbito multilateral, constituem-se em itens fundamentais à composição do programa de trabalho do CET.

Originalmente o objetivo desse comitê era examinar a relação entre medidas comerciais e medidas ambientais visando ao desenvolvimento sustentável. Ademais, objetivava a recomendação de modificações apropriadas das provisões do sistema multilateral do comércio, identificando e discutindo ligações entre a agenda de negociações e políticas econômicas.

Percebe-se, assim, que a questão ambiental ganhou seu lugar nas discussões acerca do comércio internacional, visando com isso ao desenvolvimento sustentável. No Brasil, o direito ao meio ambiente apenas surge como direito fundamental em 1988, com a Constituição Federal. ${ }^{3}$

Por fim, na Rodada Doha, nona rodada de negociação comercial multilateral da história, iniciada oficialmente em Doha (Qatar), em novembro de 20014, cujo nome formal é Agenda Doha de Desenvolvimento, foram retomadas as discussões da Rodada Uruguai, encerrada em Marrakech (Marrocos - 1994). Observe-se que, após importantes declarações sobre o desenvolvimento, como a Declaração das Nações Unidas sobre o Direito ao Desenvolvimento, de 1986, e a Conferência Mundial sobre Direitos Humanos - Viena, 1993 -, o objetivo das negociações dessa nona rodada era conseguir a abertura de mercado nos setores agrícola, industrial e de serviços, em benefício prioritário dos países menos desenvolvidos e em desenvolvimento, haja vista que, naquele período, os chamados direitos de solidariedade (direito à paz, direito ao desenvolvimento, direito ao meio ambiente saudável etc.) já se afirmavam como exigência de direito internacional (direitos humanos) e direito doméstico (direitos fundamentais).

A segunda conferência ministerial dessa rodada - conhecida como Conferência Ministerial de Cancun (México) - ocorreu em setembro de 2003, mas restou fracassada por um confronto que se concentrava no capítulo agrícola. Essa rodada contou com intensa participação do grupo G20 (países em desenvolvimento) e G90 (países menos desenvolvidos).

Dispõe o art. 225 da CF./88 que: "Todos têm direito ao meio ambiente ecologicamente equilibrado, bem de uso comum do povo e essencial à sadia qualidade de vida, impondo-se ao Poder Público e à coletividade, o dever de defendê-lo e preservá-lo para as presentes e futuras gerações".

4 A Rodada Doha teve início logo após os atentados terroristas nos Estados Unidos, momento de plena crise da economia mundial, pelo que se fazia necessária a adoção de novas medidas capazes de reativar o comércio multilateral. 
Mesmo diante do fracasso da conferência de Cancun, em julho de 2004, houve uma nova reunião ministerial da OMC, desta vez em Genebra, para retomada das negociações. Essa conferência foi marcada por um grande avanço, qual seja, os Estados Unidos e a União Européia se prepuseram reduzir seus subsídios agrícolas. Importante ainda destacar que a Rodada Doha deveria ter sido concluída em dezembro de 2004, mas foi adiada para fins de 2005 e depois indefinidamente, diante das dificuldades encontradas. Observa-se que um dos grandes impasses das negociações diz respeito aos subsídios agrícolas, que continuaram sendo concedidos pelos Estados Unidos e pela União Européia aos seus produtores.

Conforme previsto na agenda, em dezembro de 2005, houve uma nova Conferência Ministerial, desta vez em Hong Kong, a qual já se iniciou sob ameaça dos fracassos das negociações anteriores, sendo, todavia, alavancada pela promessa dos países desenvolvidos de eliminar todos os subsídios às exportações e adotar medidas de apoio às nações menos desenvolvidas até 2013, o que ajudou a reconduzir o processo. Nesse sentido, foi acordado que até 2006 deveria haver resultados concretos, e que a rodada se encerraria naquele ano, mas as negociações formam suspensas pelas dificuldades de consenso sobre os acordos o, que na prática representou nenhum avanço significativo nas negociações.

Como resultado do Fórum Econômico Mundial, realizado em Davos (Suíça), em janeiro de 2007, as negociações da Rodada de Doha foram retomadas oficialmente em Genebra, sete meses depois de terem sido suspensas. Em julho de 2008 ministros de 30 países se reúniram em Genebra, convocados pelo diretor-geral da OMC, com o objetivo de salvar a Rodada Doha, mas as negociações fracassaram novamente por falta de acordo, principalmente, quanto à agricultura.

Diante do fracasso da nona rodada de negociações multilaterais da OMC Rodada Doha - restou aos países dar maior ênfase aos acordos de livre comércio bilaterais ou regionais, haja vista a necessidade de desenvolvimento. Entretanto, abandonar a cooperação econômica multilateral é uma conduta arriscada, considerando a força que os países desenvolvidos possivelmente terão nessas negociações. A cooperação internacional e a solidariedade internacional são necessárias para que se possa enfrentar os desafios atuais do mundo em matéria de segurança, estabilidade, desenvolvimento e proteção ambiental. ${ }^{5}$

\footnotetext{
A perspectiva é que, com a conscientização da importância do respeito ao meio ambiente, como pressuposto necessário para que a humanidade possa gozar de uma sadia qualidade de vida, assim como garantir a sobrevivência das futuras gerações, haja uma profunda interação entre o mercado e o meio ambiente, cujo resultado certamente será a preservação do direito à vida e demais direitos humanos. Mas para que seja possível realizar tal interação e obter seus desejados resultados, é indispensável a solidariedade entre as nações, representada pela imposição do direito ao desenvolvimento (sustentável) dos Estados e de mudança na postura
} 


\section{Objetivos, Princípios e Normas da OMC}

O Acordo Constitutivo da OMC tem como metas: (i) incentivar a melhor utilização dos recursos mundiais, por meio de um desenvolvimento sustentável; (ii) aumentar o padrão de vida mundial; (iii) assegurar o pleno emprego e garantir um crescente volume de receitas e demanda efetiva; além de pretender (iv) expandir a produção e o comércio de bens e de serviços.

Para atingir esses objetivos, alguns princípios fundamentais estão presentes nos acordos da OMC, os quais resultam dos princípios do GATT-47, dentre os quais podemos citar: (i) o comércio sem discriminação; (ii) a transparência; (iii) a previsibilidade e a melhoria no sistema de acesso a mercados; (iv) a proibição de restrições quantitativas; (v) a consolidação dos direitos aduaneiros; (vi) a redução progressiva das proteções tarifárias; (vii) a cláusula da nação mais favorecida ${ }^{6} \mathrm{e}$ (viii) o tratamento nacional.

Perceba-se que, desde a sua criação, a OMC já demonstrava em sua normativa uma preocupação com o meio ambiente. Tal afirmativa evidencia-se especialmente pela meta base da OMC de incentivar a melhor utilização dos recursos mundiais, leia-se, dos recursos naturais, por intermédio do desenvolvimento sustentável. A esse respeito, cumpre destacar que, atualmente, a proteção do meio ambiente, garantida pelo direito ambiental, não está dissociada do desenvolvimento econômico e social, visto que o homem é um ser social e vive dessas relações, com tendência a evoluir.

Assim, tal evolução somente poderá se desenvolver na medida em que se assuma a natureza como um bem imprescindível à vida e à saúde humana, sendo, porém, esgotável, o que nos obriga a cuidar dos recursos naturais e preservar o meio ambiente em suas relações sociais e de comércio. Não é por outro motivo que o desenvolvimento sustentável, pilar do direito ambiental, está previsto como meta base da OMC em seu Ato Constitutivo.

Cabe destacar que a evolução histórica dos direitos humanos ocorre quando a comunidade social reconhece o valor desses direitos. Foi a partir desse reconheci-

do mercado perante o meio ambiente, a fim de que seja efetiva e amplamente exercida a responsabilidade socioambiental como, por exemplo, pela implementação da idéia de commodities ambientais, originadas de recursos naturais em condições sustentáveis e constituídas por um complexo produtivo que envolve matrizes como água, energia, minério, biodiversidade, madeira, reciclagem e controle de emissão de poluentes..

6 A cláusula da nação mais favorecida significa que todos os países membros da OMC têm de conceder aos demais países o mesmo tratamento especial que concederem a qualquer país.

7 Pelo princípio do tratamento nacional são vedadas quaisquer formas de discriminação entre produtos nacionais e produtos similares importados. 
mento que se concebeu uma nova perspectiva à dignidade da pessoa humana, por uma nova orientação e um novo conteúdo, como conseqüência da conexão entre os direitos humanos e o parâmetro solidário atual, o que ocorre pela dinamogenesis. ${ }^{8}$

Dentro dessa perspectiva, ensina Willis Santiago Guerra Filho:

[...] Mais importante é que os direitos gestados em uma geração, quando aparecem em uma ordem jurídica que já traz direitos de geração sucessiva, assumem outra dimensão, pois os direitos da geração mais recente tornam-se um pressuposto para entendê-los de forma mais adequada - e, conseqüentemente, também para melhor realizá-los. Assim, por exemplo, o direito individual da propriedade, num contexto em que se reconhece a segunda dimensão dos direitos fundamentais, só pode ser exercido observando-se sua função social, e com o aparecimento da terceira dimensão, observando-se, igualmente, a função ambiental. ${ }^{9}$

Portanto, a característica da historicidade dos direitos humanos pode ser explicitada como reflexo dos anseios sociais que passam a ser traduzidos como paradigmas da sociedade em determinadas coordenadas de espaço e de tempo, sempre respeitando um conteúdo ético comum, que se desdobra ao longo dos tempos por intermédio de valores de apreensão concreta.

Nesse contexto, podemos dizer que o meio ambiente é um novo paradigma ao livre comércio. Assim, em nome da proteção da vida e da saúde das pessoas é possível se impor em certas balizas ao princípio do livre comércio multilateral. Trata-se de barreira não tarifária ambiental que, se comprovadamente necessária, se torna legítima, pois visa à proteção de bens maiores, como a vida e a saúde das presentes e futuras gerações.

Todavia, o paradigma ambiental é claramente ilegítimo quando o objetivo não é a proteção ao meio ambiente, mas sim, beneficiar de forma camuflada o mercado interno, na medida em que, para se adotar uma exceção ambiental à regra do livre comércio multilateral, necessário se faz atender ao princípio da não discriminação, um dos princípios basilares dos acordos da OMC. Ressalte-se que o princípio da não discriminação é amplamente valorizado em tais acordos, podendo ser identificado, inclusive, em outros princípios, como o acesso a mercados, a cláusula da nação mais favorecida e o tratamento nacional, instrumentos concretizadores desse princípio.

8 O processo de "dinamogenesis" significa o nascimento/criação (gênesis) dinâmico de direitos humanos por intermédio de fatos sociais canalizados por agentes ou atores sociais (protecionistas), que de tempo em tempo captam as necessidades da humanidade e passam a reivindicálas como concretização/adensamento da dignidade humana. Nesse sentido, já tivemos os direitos de liberdade, igualdade e hoje nos encontramos na perspectiva da solidariedade.

9 GUERRA FILHO, Willis Santiago. Processo constitucional e direitos fundamentais. São Paulo: RCS Editores, 2005, p. 46-47. 
As questões ambientais podem, assim, se tornar restrições admissíveis e legítimas ao comércio, quando visem à tutela da vida e da saúde das pessoas, animais e vegetais (GATT-94, art. XX, "b”) e (ii) quando se tratar de medidas relativas à conservação dos recursos naturais esgotáveis, sob a condição de que tais medidas sejam aplicadas juntamente com as restrições à produção ou ao consumo nacionais (GATT-94, art. XX, “g”).

Conforme acima frisado, é importante lembrar que a exceção ambiental pode ser usada ardilosamente como pretexto para proteger o mercado diante da dificuldade de aplicação das medidas tradicionais como tarifas, cotas e entraves burocráticos. Quando for assim, evidencia uma exceção ambiental ilegítima e camuflada, uma vez que seu verdadeiro objetivo é o privilégio ao mercado interno. O caso da gasolina importada pelos Estados Unidos, o qual estudaremos mais adiante, foi considerado um exemplo de barreira não tarifária ambiental iliegitima por disfarçar medidas protecionistas.

\subsection{Acesso a Mercados}

É nítido que o principal objetivo da OMC é expandir a produção e o comércio de bens e serviços. Porém, tal meta, assim como as demais, deve estar pautada nos já mencionados princípios adotados pela $\mathrm{OMC}$, dos quais podemos destacar o princípio do acesso a mercados.

Nesse sentido, o acesso a mercados $^{10}$ é um meio de liberalização do comércio internacional, podendo ser definido como a forma pelo qual o governo de um país propiciará, aos demais países-menbros condições para a entrada de produtos importados no território nacional, sem medidas discriminatórias.

A esse respeito, é possível verificar duas categorias de obstáculos de acesso a mercados de bens ou mercadorias no âmbito da OMC, quais sejam: (i) tarifas aduaneiras e (ii) restrições não tarifárias. Quanto às barreiras não tarifárias, se trata de toda e qualquer medida que não seja uma tarifa e que vise privilegiar a indústria doméstica. De uma maneira geral, as principais barreiras não tarifárias são as barreiras quantitativas, sanitárias, fitossanitárias, cambiais, ambientais, de licenciamento de importações, relativas ao desembaraço aduaneiro, de rotulagem, etiquetagem, sociais ou laborais (referentes ao processo produtivo da mercadoria ou serviço), de medidas, técnicas e de valoração aduaneira.

$\overline{10}$ No âmbito do GATT-94, são os seguintes os dispositivos que tratam do tema acesso a mercados: artigos II; V; VII; VIII; IX; X; XXIV e XXV. 
São consideradas práticas desleais do comércio internacional a imposição de barreiras não tarifárias referentes a subsídios, ${ }^{11}$ dumping ${ }^{12}$ e medidas de salvaguar

$\mathrm{da}^{13}$ injustificáveis. Tais práticas autorizam a adoção de medidas de defesa comercial, à exceção das regras do sistema de comércio multilateral, que objetivam a liberalização comercial. Assim, as medidas de defesa comercial foram criadas como mecanismo legal de proteção da indústria doméstica, prejudicada ou ameaçada pela prática desleal do comércio, mas não restrita a ela, pois o Estado poderá adotar tais medidas sempre que a concorrência de produtos importados coloque em risco o mercado nacional, ainda que não esteja caracterizada a conduta desleal do exportador. Todavia, a imposição de barreiras legítimas à importação de produtos é exceção, pois o que se almeja é o pleno desenvolvimento dos países, especialmente os menos desenvolvidos, pela mais ampla liberalização do comércio internacional.

É possível observar da análise dos casos apresentados ao OSC (Órgão de Solução de Controvérsias) da OMC, dos quais destacaremos dois para estudo neste trabalho, que a maior parte dos entraves no comércio internacional está no amplo arsenal de medidas não tarifárias, utilizadas pelos países como forma beneficiar setores de sua economia interna, assim como para tornar mais competitivo determinado produto no mercado internacional. No que tange à proteção ao meio ambiente, a barreira não tarifária poderá ser utilizada se legítima e necessária, observadas, todavia, a adequação da medida aos demais princípios da OMC como, v.g., o princípio de acesso a mercados.

11 Subsídios são incentivos financeiros concedidos pelo governo de determinado país em benefício de uma indústria específica. Caso a concessão desses subsídios prejudique indústria específica de outro país, dependendo do tipo de subsídio concedido, este poderá demandar na OMC para que a norma que estabelece a concessão do subsídio seja revogada ou poderá adotar medidas compensatórias para neutralizar o prejuízo sofrido em decorrência da concessão desses subsídios.

12 O dumping ocorre sempre que uma empresa exporta produto por preço inferior ao praticado no mercado interno. Para que o dumping seja considerado prática desleal do comércio é necessário que haja um real prejuízo ou ameaça à indústria doméstica relativamente àquele produto importado a preço dumping. As medidas antidumping têm por objetivo evitar que os produtores nacionais sejam prejudicados por importações de produtos a preço dumping. Nesse caso, para proteger a indústria nacional, o Estado poderá valer-se de uma sobretaxa na alíquota da importação, denominada medida antidumping, para proteger o mercado interno.

13 As medidas de salvaguarda consistem no aumento da tarifa de importação ou na restrição quantitativa para importações, autorizadas sempre que a indústria nacional for prejudicada ou estivar ameaçada por um surto inesperado de importações. 
$\mathrm{Na}$ contramão, temos o dumping ecológico, ${ }^{14}$ que ao contrário da barreira não tarifária ambiental - que, para proteger o meio ambiente, bloqueia as importações -, concede facilidades ao mercado interno por intermédio de uma legislação de meio ambiente demasiadamente branda. Tal conduta estimula o desenvolvimento econômico interno à custa da agressão ao meio ambiente, inclusive para atrair investimento estrangeiro no país, já que a lógica do mercado tende a buscar o menor custo, o que indubitavelmente é proporcionado quando se tem uma legislação ambiental pouco exigente, resultando certamente na obtenção de maior vantagem econômica por parte dos investidores.

\subsection{Princípio da Solidariedade}

O desenvolvimento sustentável demanda responsabilidade de todos os Estados, designadamente pelo desafio da solidariedade. Nesse sentido, em matéria de relações comerciais internacionais, há o reconhecimento mundial do interesse comum da humanidade no desenvolvimento sustentável, a exemplo das exceções ambientais autorizadas pela normativa da OMC. Todavia, sustentabilidade versus desenvolvimento econômico é uma tarefa árdua, pois implica concessões, especialmente por parte dos países desenvolvidos, e o resultado dessa equação nem sempre é positivo, como no caso da fracassada Rodada Doha, em que não foi possível concluir as negociações ante a resistência dos países ricos em estimular o desenvolvimento dos países menos desenvolvidos pela agricultura.

No atual estágio da evolução dos direitos humanos, qual seja, os direitos de solidariedade, seja nos limites das fronteiras territoriais, seja nas relações transnacionais, o objetivo é a harmonia na convivência humana pela produção de maiores benefícios e pela redução dos malefícios. Assim, os direitos à solidariedade são os direitos de tutela do interesse de todos, como o direito à paz, o direito de cooperação, o direito de ao desenvolvimento, o direito ao meio ambiente equilibrado, assim como o direito à distribuição das riquezas de forma equânime por intermédio da cooperação estatal. A assimilação desses direitos e de sua real importância para a humanidade certamente resultará em maiores concessões por parte daqueles que detêm melhores condições, especialmente econômicas, assim como poder de decisão, relativamente às relações que afetam diretamente o interesse de todos. É nesse

14 Dumping ecológico é a instituição por um país, normalmente pouco desenvolvido, de uma legislação ambiental fraca e mais favorável às indústrias a fim de atrair investimentos, visto que os custos serão menores diante das vantagens econômicas de uma lei ambiental pouco exigente. O dumping ecológico tem em comum com o dumping de preços unicamente o aproveitamento pelo produtor de uma situação especial desse mercado, cuja legislação ambiental pouco exigente oferece condições para a prática de baixos preços, potencializando a competitividade. Essa circunstância também é conhecida como prática desleal do comércio. 
sentido que se fala em obrigações comuns, porém diferenciadas, como estabelece o Protocolo de Quioto, que reconhece o maior grau de responsabilidade dos países industrializados pelo aquecimento global e imputa a estes obrigações mais significativas do ponto de vista absoluto das metas compulsórias de redução das emissões. ${ }^{15}$

\subsection{Tratamento Nacional}

Conforme foi acima mencionado, para atingir os objetivos ou metas-base da OMC, alguns princípios foram criados para garantir maior efetividade e melhor interpretação daqueles objetivos iniciais. Um desses princípios, conforme foi acima observado, é o princípio do acesso a mercados, outro é o princípio do tratamento nacional.

O tratamento nacional é dividido em: (i) discriminação de jure e (ii) discriminação de facto. A discriminação de jure se caracteriza por medidas normativas discriminatórias em que os produtos domésticos são tratados de forma diversa dos produtos importados. Já a discriminação de facto é caracterizada por medidas que não mencionam expressamente que serão discriminados, do ponto de vista tributário, os produtos importados em relação aos similares nacionais. Mas na prática é possível identificar essa discriminação, como pode ocorrer, por exemplo, na contratação pública de software quando existir uma forma de software obrigatória ou preferida por um Estado/Governo.

Neste breve estudo, a compreensão do tratamento nacional visto do enfoque da discriminação de jure é o que realmente interessa ${ }^{16}$ para que possamos, mais adiante, analisar e refletir acerca do primeiro e do último caso levados ao OSC - Órgão de Solução de Controvérsias - da OMC, quando teremos a oportunidade de verificar a aplicação prática dos objetivos, princípios e normas da OMC, especialmente no que tange à proteção do meio ambiente por intermédio de um desenvolvimento sustentável.

Antes de adentrarmos no estudo dos casos, cumpre destacar, o mais minuciosamente possível, a integração entre o Direito do Comércio Internacional e meio ambiente.

$\overline{15}$ Atualmente a, Convenção sobre Mudanças Climáticas da ONU (COP) pretende lançar as bases de combate ao aquecimento global a ser adotada a partir de 2012, após o término da vigência do Protocolo de Quioto.

16 A discriminação de facto deve ser estudada caso a caso, pois traz situações específicas, que demandam uma interpretação, na maioria, indutiva e dialética. 


\section{Comércio Internacional e Meio Ambiente}

Existe atualmente uma perspectiva integrativa entre comércio internacional e meio ambiente, tendo por fundamento o desenvolvimento sustentável. ${ }^{17}$ Dessa perspectiva, a relação entre comércio internacional e meio ambiente deve ser pautada pela racionalização do uso dos meios ambientais em busca do desenvolvimento econômico associado a uma melhor qualidade de vida humana, presente e futura.

Nesse particular, importante destacar que é o interesse comum da humanidade que determina toda ação com vistas à tutela do meio ambiente. Quanto à noção de "interesse comum da humanidade," Alexandre Kiss faz as seguintes considerações ao tentar dar uma resposta ao seu significado:

Com certeza, em primeiro lugar, a sobrevida da humanidade, mas também a possibilidade para os indivíduos e para os povos que a compõem de levar uma vida material satisfatória, na dignidade e na liberdade. É necessário ressaltar que quando falamos em humanidade deve-se entendê-la não somente no presente mas também no futuro: as condições de existência das gerações futuras - que serão cada vez mais numerosas, pelo menos durante algumas décadas - não devem ser mais desfavoráveis que aquelas que nós herdamos de nossos predecessores. Este direito das gerações futuras é na realidade inscrito em tudo o que diz respeito à proteção do meio ambiente e à preservação dos recursos naturais: a conservação só tem sentido dentro de uma perspectiva temporal; caso contrário tudo poderia ser consumido e desperdiçado no presente. ${ }^{18}$

Assim, a perspectiva integrativa baseia-se na intenção comum da humanidade de identificar os problemas e elaborar soluções tendentes a equacionar, da melhor maneira possível, a relação entre crescimento econômico e danos ambientais, gerados dessa relação, já que não é somente a vida que está em jogo, mas também a satisfatória qualidade de vida, tanto no presente como no futuro. Vale destacar que, para tanto, e indispensável o desenvolvimento da tecnologia de recursos de produção ecologicamente corretos, vontade política e pesado investimento financeiro.

Atenta a essa realidade, a Organização Mundial do Comércio adotou o desenvolvimento sustentável como um dos seus objetivos, abrindo, assim, uma exceção ambiental ao comércio internacional, prevista no art. XX do GATT-97, parágrafos "b" e "g". ${ }^{19}$

17 O conceito de desenvolvimento sustentável foi mencionado pela primeira vez no documento "A Estratégia Mundial para a Conservação", elaborado em 1972 pelo programa das Nações Unidas para o Meio Ambiente (PNUMA), pela União Internacional para Conservação da Natureza (UICN) e pelo Fundo Mundial para a Vida Selvagem (WWF). Vide: PROCÓPIO FILHO; VAZ; TACHINARDI, M. H. Ecoprotecionismo: comércio internacional, agricultura e meio ambiente. Brasília: IPEA,1994, p. 10.

18 KISS, Alexandre. Droit international de l'environnement. Paris: Editions A. Pedone, 1889, p.15.

19 Art. XX, do GATT-94, parágrafos “b”: medidas necessárias à proteção da saúde e da vida das 
Destarte, sempre que a relação de comércio internacional, ou seja, a importação de determinado produto cause ou tenha o potencial de causar dano à vida e à saúde das pessoas e dos animais, assim como dos vegetais, afetando com isso o interesse comum da humanidade, poderá o Estado tomar as medidas necessárias à proteção destes bens por intermédio de leis e regulamentações restritivas ao comércio internacional, sem que isso seja considerado uma violação ao acordo multilateral de livre comércio. Importante salientar que assim será desde que seja comprovadamente necessária a adoção de tais medidas.

Todavia, é certo que, por ser exceção, a essas medidas devem anteceder outras, como, v.g., o pleno investimento na diminuição do impacto ambiental causado pela atividade produtiva. Nesse sentido, ensina Henry Iure de Paiva Silva que:

(...) Não decorre necessariamente da expansão comercial o problema da degradação ambiental, contudo, seus efeitos contraproducentes podem ser potencializados em virtude de práticas ineficientes tanto do setor privado - que deveria internalizar os custos ambientais em suas respectivas atividades econômicas - como do setor público - cujo papel não apenas é de repressão, mas também o de promover a conscientização dos setores econômicos e da população em geral sobre a importância e os benefícios decorrentes de uma conduta ambiental correta. ${ }^{20}$

De fato administrar os conflitos inevitavelmente decorrentes da relação entre comércio e meio ambiente, seja no âmbito nacional seja internacional, é responsabilidade de todos, especialmente, dos Estados, no que tange às políticas públicas de conscientização geral e imposição legal ao setor produtivo, potencialmente causador de danos ao meio ambiente. Frise-se que a adoção de medidas mais eficazes para que a atividade econômica cause o menor dano possível ao meio ambiente vai ao encontro do princípio do desenvolvimento sustentável.

É nesse sentido que, conforme já elucidado, o Protocolo de Quioto, instrumento internacional que reflete a preocupação mundial com a preservação ambiental, especialmente com a diminuição de emissão de dióxido de carbono $\left(\mathrm{CO}^{2}\right)$, diante das desastrosas consequências advindas de sua destruição, estabelece que:

As partes incluídas no Anexo I devem esforçar-se para implementar políticas e medidas ao abrigo do presente artigo, de forma a minimizar os efeitos adversos, incluindo os efeitos adversos das alterações climáticas, os efeitos do comércio internacional e sociais, ambientais

pessoas e dos animais e à preservação dos vegetais e "g": medidas necessárias para assegurar o respeito às leis e regulamentações; e medidas relacionadas à conservação de recursos naturais.

20 SILVA, Henry Iure de Paiva. Interação entre comércio internacional e meio ambiente. Disponível em: <http://www.ccj.ufpb.br/primafacie/prima/artigos/n6/interacao.pdf>. Acesso em: 22 jan. 2008. 
e econômicos em outras partes, especialmente países em desenvolvimento e em especial as partes identificadas no Artigo $4^{\circ}$., $\mathrm{n}^{\text {os }} 8$ e 9 da Convenção, tendo em conta o artigo $3^{\circ}$ da Convenção..$^{21}$

Extrai-se de tal dispositivo o interesse internacional pela implementação de políticas e medidas pelos Estados-Partes tendentes a minimizar os efeitos danosos da produção industrial, diretamente relacionada ao comércio internacional, por intermédio da cooperação internacional e efetiva implementação das políticas do Estado cooperativo, em nome da solidariedade e do interesse comum de tutela dos direitos humanos, preocupando-se, inclusive, com as diferenças existentes entre os países desenvolvidos e em desenvolvimento, uma vez que o investimento em equipamentos ecologicamente corretos ou menos danosos ao meio ambiente demanda alto investimento, inviável às economias mais fracas ou menos desenvolvidas, o que torna transparente a necessidade da cooperação internacional, pela transferência de tecnologia, intercâmbio de informações sobre tais políticas e medidas, ou até mesmo por intermédio de investimento direto dos países desenvolvidos nas economias mundiais mais fracas, em prol do meio ambiente com vistas ao desenvolvimento sustentável. ${ }^{22}$

O interesse internacional na tutela do meio ambiente, nos termos acima expostos, e a cooperação entre os Estados por intermédio do intercâmbio de informações e do investimento, indubitavelmente, ajudará a preservar a dinâmica do comércio internacional sob o enfoque do desenvolvimento sustentável, respeitando, porém, os limites impostos pela soberania. Assim, no tocante à relação entre comércio e meio ambiente, continuam os Estados soberanos autorizados a impor medidas restritivas ao comércio internacional com vistas à garantia da proteção de bens maiores, que se sobrepõem à liberdade comercial, tais como a vida e a saúde humana.

Ocorre que tanto as medidas ambientais restritivas, como a imposição de sanções ao setor privado ambientalmente incorreto tendem a desacelerar a economia uma vez que impedem que os países em desenvolvimento ou não desenvolvidos possam acompanhar os níveis de proteção ambiental estabelecidos pelos países desenvolvidos, diminuindo assim as exportações e enfraquecendo suas economias. Nesse sentido, reforça-se a importância do Estado cooperativo no seu novo papel de solidariedade e compartilhamento de experiências e intercâmbio de informações

\footnotetext{
21 Art. 2., 3.

22 A título de exemplo, podemos citar o investimento da Noruega em projetos sustentáveis na Amazônia. A Noruega foi o primeiro país a aportar recursos no Fundo Amazônia. Em 25 de março de 2009, foi assinado o contrato com o BNDES - Banco Nacional de Desenvolvimento Econômico e Social -, quando foram repassados U\$ 125 milhões, a título de doação ao fundo. O compromisso da doação é de U\$ 500 milhões, mas o país sinalizou que esse aporte poderá chegar a U\$ 1 bilhão. O financiamento dos projetos será na modalidade não reembolsável.
} 
quanto a políticas e medidas para o desenvolvimento sustentável, incluindo a criação de formas de melhorar sua comparabilidade, transparência e eficácia ${ }^{23}$ numa perspectiva solidária, o que se evidencia pela transferência de tecnologia e investimento direto nos países em desenvolvimento, entre outras possibilidades.

Nesse diapasão, vale ressaltar que, quanto ao princípio que garante o direito soberano dos Estados estabelecerem seus próprios níveis de proteção ambiental, tais padrões ainda são livremente determinados por cada Estado, haja vista a disparidade existente entre um Estado e outro, especialmente no que tange ao nível de desenvolvimento e ao interesse em receber investimentos. Todavia, essa liberdade encontra certos limites, estabelecidos pelos princípios da OMC, conforme já estudado, especialmente quanto às barreiras ao comércio internacional ou, opostamente, pela adoção de uma legislação ambiental demasiadamente branda, o que pode caracterizar o dumping ecológico, mecanismo que distorce completamente o princípio da soberania, em confronto com o princípio da solidariedade, visto que o menor nível de proteção dado pela legislação ambiental não decorre de sua condição de país em desenvolvimento, mas sim do interesse econômico em privilegiar o mercado interno com uma legislação ambiental pouco exigente, atraindo assim mais investimentos.

Há que se considerar, entretanto, que a assimetria nos níveis de desenvolvimento dos Estados ainda é patente nos dias de hoje, o que impossibilita os países em desenvolvimento acompanharem os padrões de proteção ambiental estabelecidos pelos países desenvolvidos, pois ainda é extremamente custoso investir em tecnologia de produção ambientalmente correta, conforme foi acima salientado. Cite-se, a título de exemplo, o caso da Proibição de Importações de Camarão pelos Estados Unidos (WT/DS 61 - United States - Import prohibition of certain shrimp and shrimp products), objeto de análise pelo OSC da OMC. Em suma, os Estados Unidos proibiram a importação de camarões cultivados com tecnologia que pudesse afetar desfavoravelmente determinados tipos de tartarugas marinhas, afetando com essa proibição a exportação de camarões pelos países não desenvolvidos ou em desenvolvimento aos Estados Unidos, pois evidentemente aqueles não dispunham de condições financeiras para investir em tecnologia eficaz de atividade pesqueira e preservação das tartarugas marinhas. ${ }^{24}$

Estudos realizados pela UNCTAD - Conferência das Nações Unidas para Comércio e Desenvolvimento ${ }^{25}$ - apontam a freqüência, cada vez maior, da utiliza-

\footnotetext{
$\overline{23}$ Protocolo de Quioto, art. 2',1, "b”.

24 O Painel da OMC, apoiado pelo Órgão de Apelação, concluiu que as medidas todas pelos EUA não eram justificáveis pelo artigo XX do GATT-94.

25 UNCTAD, 2005, p.9.
} 
ção pelos países desenvolvidos de requisitos ambientais, rigorosos e complexos, em determinados setores, dificultando o acesso a mercados pelos países em desenvolvimento. Já em 2004, o relatório da UCNTAD demonstrou que os países em desenvolvimento têm motivos para se preocupar com o aumento das barreiras comerciais com fins ambientais, pois os países desenvolvidos têm criado regulamentos ambientais em vários setores nos quais os países em desenvolvimento têm se tornado particularmente competitivos, como produtos provenientes da pesca e do setor de base florestal, couro, produtos têxteis e alguns bens de consumo.

Nesse sentido, alertam Young e Lustosa que a busca de equilíbrio dos fluxos comerciais tem levado países desenvolvidos a

(...) impor barreiras não tarifárias - "barreiras verdes" -, alegando que os países em desenvolvimento possuem leis ambientais menos rigorosas que as suas, o que resultaria em custos mais baratos - também chamado dumping ecológico - e, conseqüentemente, menores preços praticados no mercado internacional. ${ }^{26}$

Ressalte-se que, em casos assim, onde os níveis de proteção ambiental dos países em desenvolvimento são menores do que os estabelecidos pelos países desenvolvidos, ao invés da imposição de barreira não tarifária ambiental, o ideal é que se prime pela cooperação internacional, compatibilizando-se os interesses comerciais e ambientais da perspectiva do direito ao desenvolvimento. Para tanto, seria necessária uma política internacional de cooperação entre as nações, especialmente no que tange à transferência de conhecimento científico e tecnológico, além da concessão de recursos financeiros aos países em desenvolvimento, para que possam implementar medidas de proteção ambiental adequadas e compatíveis com o desenvolvimento sustentável. ${ }^{27}$

Inegável a complexidade do tema, uma vez que a relação entre competitividade e proteção ao meio ambiente é naturalmente conflitante, pois quando o que se pretende é potencializar a competitividade a busca é pelo menor preço, ao passo que o investimento na proteção ambiental demanda gastos que elevam consideravelmente o investimento e consequentemente o preço final do produto. Equacionar essa relação não é tarefa fácil, pois temos nesse caso o embate de dois grandes interesses;

26 YOUNG, Carlos E. F.; LUSTOSA, Maria C. J. Meio ambiental e competitividade na indústria brasileira. Revista de Economia Contemporânea, Instituto de Economia - UFRJ, v. 5, n. especial, ano 2003, p. 10.

27 Protocolo de Quioto, art. 2 . "v". Com esse espírito de tutela do meio ambiente, o Protocolo de Quioto, Convenção Quadro das Nações Unidas sobre Alterações Climáticas, refletindo a preocupação mundial com a agressão ao meio ambiente e seus reflexos para a vida humana, prevê a redução progressiva ou eliminação gradual do mercado, de incentivos fiscais, isenções fiscais e subsídios em todos os setores emissores de gases que são contrários ao objetivo de evitar os danos ambientais causados pela alteração climática. 
o crescimento econômico e a tutela ao meio ambiente em prol da vida e da saúde humana. O resultado esperado é a necessária cooperação de todos, especialmente dos países desenvolvidos, curvando-se o interesse econômico ao princípio da solidariedade em nome da dignidade e da continuidade da humanidade.

Diante desse quadro, a solução fica por conta da conscientização da necessidade de o mercado adotar e cumprir regras compatíveis com as exigências ambientais, as quais devem ser ajustadas para os países em desenvolvimento e dinamizadas pela cooperação internacional no que tange à transferência de tecnologia e intercâmbio de informações. Como resposta a esse reclamo, já podemos sentir os primeiros passos rumo à implementação de medidas voltadas para a sustentabilidade, como no caso de análise de crédito para investidores, ou seja, a existência de risco ambiental é considerada risco de crédito da empresa, pois eleva seus custos financeiros, implicando a diminuição das receitas dos acionistas. Por isso, tais condições são levadas em conta na decisão das condições de concessão de crédito pelos bancos e também pelos investidores, que preferem aplicar seu capital em empresas livres de riscos ambientais. $^{28}$

Ocorre que a efetividade do compromisso com a sustentabilidade ambiental, para surtir efeitos positivos, deve pautar-se não apenas em políticas de conscientização, mas inclusive em um sistema repressivo, com imposição de graves sanções aos descumpridores da obrigação de cooperação e solidariedade no tocante à tutela do meio ambiente e ao desenvolvimento sustentável. Do contrário, dificilmente, tal debate será eficiente, haja vista os interesses conflitantes que estão em jogo, conforme ficou acima demonstrado.

Por derradeiro, cumpre mencionar que muitos países desenvolvidos apoiam a implementação de programas voluntários de certificação, que envolvem critérios relacionados às características dos métodos de produção, desde que apoiadas em regras de certificação multilateralmente aceitas. Com efeito, a cooperação internacional, aglutinando Estados e Organizações Internacionais, baseada num paradigma de solidariedade, pautada no desenvolvimento sustentável, apresenta-se como a solução mais viável.

28 Cf. Dionis Mauri Penning Blank e Maria Claudia Crespo Brauner. A responsabilidade civil ambiental das instituições bancárias pelo risco ambiental produzido por empresas financiadas. Disponível em: < http://www.remea.furg.br/edicoes/vol22/art19v22.pdf.> Acesso em: 28 ago. 2009. 


\section{Casos Práticos}

Expostas as premissas acima, isto é, feitas as devidas considerações acerca dos objetivos, princípios e normas ambientais da $\mathrm{OMC}$, assim como uma breve análise da relação entre comércio internacional e meio ambiente, iremos a seguir expor dois casos levados ao Órgão de Solução de Controvérsias da OMC para enfim observarmos a aplicação prática de sua normativa de proteção ambiental.

Escolhemos dois casos envolvendo matéria ambiental para desenvolvermos uma reflexão jurídica quanto à relação entre comércio internacional e meio ambiente, quais sejam, o primeiro caso levado OSC da OMC - caso das normas dos Estados Unidos da América para gasolina reformulada - e também o recente caso da proibição, pelo Brasil, de importação de pneumáticos remoldados, levado ao OSC da OMC pela União Européia, justamente para observarmos eventual evolução das decisões da OMC acerca da proteção ao meio ambiente. Ambos os casos escolhidos para estudo envolvem matérias ambientais, todavia, não são os únicos.

\subsection{Caso das normas dos Estados Unidos para a gasolina reformulada e convencional}

Esse caso foi a primeira disputa examinada pelo Órgão de Solução de Controvérsias após a entrada em vigor da OMC. Trata-se de reclamação apresentada por dois países em desenvolvimento, Venezuela e Brasil, contra um país desenvolvido, os Estados Unidos. É interessante notar que, durante a vigência do antigo GATT-47, quase sempre eram os países desenvolvidos que promoviam queixas entre eles ou os países desenvolvidos reclamavam de um país em desenvolvimento. Talvez este seja o primeiro sinal de que os países membros da OMC, em particular, os chamados em desenvolvimento, se sentiram mais confiantes no novo sistema de resolução de disputas da OMC.

Os fatos da queixa são simples. Trata-se de reclamação proposta pela Venezuela e pelo Brasil, alegando incompatibilidade da legislação dos EUA, especialmente, o Clean Air Act - Lei do Ar Limpo - 1990 (CAA) ${ }^{29}$ com o artigo III:4 do GATT-94. Segundo a reclamação apresentada, a agência norte-americana U.S. Environmental Protection Agency - Agência de Proteção Ambiental - (EPA) editou, fundamentada no CAA, a Regulation of Fuels and Fuel Additives - Standards for Reformulation and Conventional Gasoline - Regulamentação dos Combustíveis e Aditivos para Combustíveis - Normas para a Gasolina Reformulada e Convencional.

29 Lei norte-americana que regulamenta a emissão de poluentes, aprovada em 1963, e a partir daí passando periodicamente por importantes revisões. 
A referida regulamentação norte-americana possui, de fato, preocupações com a preservação ambiental, ou seja, diminuir a emissão, na atmosfera, de substâncias tóxicas resultantes da combustão da gasolina. Nesse sentido, a regulamentação fixava "níveis de base" de toxidade da gasolina, independente da origem do produto, isto é, gasolina doméstica ou importada. Entretanto, era variável o modo de determinação dos "níveis de base". Com efeito, essa variação distinguia as refinadoras norteamericanas das demais refinadoras (sediadas fora do seu território) o que pode ser comprovado quando se constata que as refinadoras norte-americanas podiam estabelecer seus próprios "níveis de base", em detrimento das estrangeiras, que eram obrigadas a atender "níveis de base" previamente estabelecidos pela EPA. Mas isso ainda não é tudo. Os "níveis de base", preestabelecidos pela EPA, os quais estavam subordinados apenas às refinadoras estrangeiras, eram muito mais difíceis de serem atendidos e respeitados do que os das nacionais. Assim, segundo as alegações da Venezuela e o Brasil, os produtos importados recebiam um tratamento menos favorável que o acordado aos produtos similares norte-americanos. Diante disso, haveria uma discriminação entre produtos domésticos e importados, o que violaria um dos pilares da OMC, qual seja, o tratamento nacional.

Em resposta à reclamação da Venezuela e do Brasil, os Estados Unidos sustentaram que a fixação de "níveis de base" de toxidade da gasolina era uma medida prevista nas exceções do Art. XX do GATT-94, parágrafos "b" e "g" (medidas necessárias à proteção da saúde e da vida das pessoas e dos animais e à preservação dos vegetais e medidas necessárias para assegurar o respeito às leis e regulamentações; e medidas relacionadas à conservação de recursos naturais, respectivamente). Não obstante, se a medida estabelecida pela regulamentação dos EUA de fato atendesse aos requisitos do Art. XX, parágrafos "b" e "g", ela não poderia ser incompatível com as disposições do Art. III:4 do GATT-94.

Ao decidir a reclamação que lhe foi apresentada, o Painel formado teve de examinar basicamente se a gasolina importada do Brasil e da Venezuela, em virtude da nova regulamentação dos EUA, estava tendo um tratamento menos favorável que a gasolina norte-americana. Diante dessa problemática, o Painel, por fim, rejeitou o argumento dos EUA de que a gasolina importada estava recebendo o mesmo tratamento que a nacional, vez que as normas norte-americanas exigiam padrões mais rigorosos de qualidade da gasolina importada em comparação com a nacional, o que caracterizava, segundo a decisão, uma discriminação injustificada. ${ }^{30}$

Quanto à alegação norte-americana de que a medida em litígio atendia aos requisitos do Art. XX "b" do GATTT-94, o Painel não acolheu tal argumento, pois,

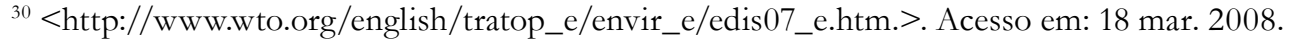


segundo o relatório, não foram apresentadas provas necessárias de que a medida objeto da reclamação é a "menos restritiva possível ao comércio". Vale notar que, no entender do Painel, "os Estados Unidos, na qualidade de parte que invoca uma exceção, tem o ônus de provar que a medida inconsistente insere-se no âmbito da exceção" prevista no Art. XX. Ainda em conformidade com a decisão, eram possíveis outras alternativas aos Estados Unidos para a proteção do meio ambiente, em especial, a implementação de uma regulamentação única, aplicável a qualquer produto, doméstico ou estrangeiro. Diante disso o Painel decidiu que o estabelecimento de "níveis de base" que permitiram um tratamento menos favorável à gasolina importada do que à nacional não visava, fundamentalmente à conservação do meio ambiente, o que resultou na desconsideração do argumento previsto no caput do Art. XX do GAT'T-94.

Os EUA ainda recorreram ao Órgão de Apelação da OMC, sustentando a mesma tese, mas o órgão considerou que as regras norte-americanas que estabeleciam níveis de base constituíam, na sua forma, uma discriminação injustificada e uma restrição disfarçada ao comércio internacional. Concluíram que houve no caso em tela uma violação ao princípio do tratamento nacional previsto no Art. III:4 do GAT'T-94, o que desautoriza como consequência a aplicação da exceção ambiental do Art. XX do GAT'T-94.

Pode-se observar assim que mesmo havendo na normativa do GATT-94, a possibilidade de aplicação de barreira ao comércio internacional, em caráter de exceção, autorizadora da restrição ambiental, esta somente se justifica se comprovadamente necessária, o que não se verificou no caso apresentado, uma vez que os EUA não se desincumbiram do ônus de provar que a exceção ambiental imposta representava o meio menos restritivo possível ao comércio.

Ademais, por fazer uma discriminação injustificada entre o produto nacional e o importado, caracterizada pela diferenciação dos padrões de qualidade exigidos da gasolina nacional e da importada, a normativa norte-americana revelou-se uma restrição disfarçada do comércio internacional, o que viola o princípio do tratamento nacional pelo qual os países partes do acordo sobre livre comércio devem dar o mesmo tratamento aos produtos nacionais e importados, devendo qualquer restrição à entrada de produtos estrangeiros ser justificadamente comprovada. 


\subsection{O Caso da Proibição do Brasil de Importação de Pneumáticos Reformados Provenientes da União Europeia no Sistema da OMC}

A disputa, que discute a restrição do Brasil à importação de pneus usados e reformados da União Europeia, foi um caso de grande repercussão e interesse mundial, tendo atraído a atenção de países do mundo todo. Nesse particular, é importante registrar que doze países se inscreveram como terceiras partes interessadas na controvérsia. ${ }^{31} \mathrm{O}$ interesse deveu-se ao fato de que, durante as discussões sobre o caso, foram abordados temas relevantes para o comércio multilateral como: (i) a relação entre comércio e meio ambiente; (ii) a relação entre regionalismo-multilateralismo e (iii) a relação entre bens usados, reformados e novos..$^{32}$

Resumidamente, temos que, em 20 de junho de 2005 a União Européia solicitou a celebração de consultas ao Brasil a respeito da imposição de medidas que afetavam desfavoravelmente as exportações de pneus usados e reformados provenientes da UE ao mercado brasileiro, abordando as seguintes medidas: (i) a imposição, pelo Brasil, de proibição de importação de pneus reformados; (ii) a adoção, pelo Brasil, de um conjunto de medidas que proíbam a importação de pneus usados, que às vezes se aplicam às importações de pneus reformados, apesar de estes não serem pneus usados; (ii) a imposição, pelo Brasil, de uma multa de 400 (quatrocentos) reais por unidade de importação, assim como a comercialização, transporte, armazenamento e conservação em depósito de pneus usados e reformados importados, e (d) a isenção outorgada pelo Brasil à importação de pneus reformados provenientes de outros países do Mercosul.

A União Europeia sustentou que as medidas mencionadas eram incompatíveis com as obrigações assumidas pelo Brasil de acordo com o parágrafo primeiro do artigo I; do parágrafo quarto do artigo III; do parágrafo primeiro do artigo XI e do

31 Ingressaram como terceiras partes interessadas: Argentina, Austrália, China, Coréia, Cuba, Estados Unidos, Guatemala, Japão, México, Paraguai, Tailândia e Território Aduaneiro Distinto de Taiwan, Penghu, Kinmen e Matsu.

32 No que tange aos pneus, podemos apresentar as seguintes definições para pneu "novo", "usado" e "reformado": Pneu novo é o que não sofreu uso nem foi submetido a qualquer tipo de reforma e que não apresenta sinais de envelhecimento nem deteriorização de qualquer origem. Pneu usado é o que foi submetido a qualquer tipo e uso e/ou desgaste. Por sua vez, pneu reformado é o reconstituído a partir de um pneu usado, em que se repõe uma nova banda de rodagem, podendo incluir a renovação da superfície externa lateral, segundo os seguintes métodos: remodelagem, recauchutagem e recapagem. O pneu remoldado é o reconstituído mediante a substituição da banda de rodagem, dos ombros e de toda superfície de seus flancos. O pneu recauchutado é o reconstituído mediante a substituição da banda de rodagem e dos ombros. Já o pneu recapado é o reconstituído mediante a substituição apenas da banda de rodagem. Fonte: $<$ www.uvb.com.br>. 
parágrafo primeiro do artigo XIII do GAT'T-94. Nesse sentido, a UE alegou que, com a barreira imposta à importação de pneus reformados da Europa, o Brasil estaria violando o princípio da $\mathrm{OMC}$ sobre livre comércio. Além de praticar tratamento discriminatório aos países da Europa, pois importa pneus remoldados do Uruguai, regularmente.

Em sua defesa o Brasil alegou que os pneus reformados podem ter consequências negativas para o meio ambiente e a saúde, até porque falta capacidade e conhecimento no país para a destruição apropriada desses pneus, haja vista sua menor durabilidade em comparação com o pneu novo, especialmente com as importações crescentes de pneus reformados originárias da UE. Porém, com relação a este argumento os árbitros apontaram para o alto volume de pneus reformados que continuam entrando no Brasil em decorrência de medidas e liminares concedidas pelo Judiciário brasileiro aos importadores. ${ }^{33}$

O Ministério do Meio Ambiente do Brasil, embora também seja contrário à entrada dos pneus uruguaios, por sua vez, entende que a possibilidade de importação de pneus usados e/ou reformados europeus é uma ameaça ainda maior ao meio ambiente, pois, em verdade, a importação de pneus remoldados ${ }^{34}$ do Uruguai é feita em pequena quantidade ${ }^{35}$ e é importante para as exportações daquele país, ao passo que a importação de pneus provenientes da Europa ${ }^{36}$ representa parcela significativa desse mercado e pouco representativa na pauta do comércio entre Brasil e União Européia. Vale lembrar que, na disputa entre Brasil e Uruguai, o primeiro foi vencido no Tribunal arbitral do Mercosul, porém se valendo apenas de argumentos comerciais e não ambientais. ${ }^{37}$

33 Com as liminares, 8 milhões de carcaças entraram no mercado apenas em 2005, apesar da barreira. Fonte: <www.mre.gov.br>. Acesso em: 07 ago. 2007.

34 A proibição, pelo Brasil, de importação de pneus "remoldados" do Uruguai foi objeto de controvérsia no Tribunal Arbitral do Mercosul.

35 São importados por ano cerca de 100 mil pneus remoldados do Uruguai contra 80 milhões da União Européia.

36 Fonte: <www.mre.gov.br>. Acesso em: 03 ago. 2007.

37 O Tratado de Assunção menciona, desde a sua criação, que a integração sub-regional é uma condição fundamental para acelerar o desenvolvimento econômico com justiça social, acrescentando que tal objetivo deve ser alcançado mediante o mais eficaz aproveitamento dos recursos disponíveis e a preservação do meio ambiente, entre outras solicitações e princípios. Todavia, na disputa que envolveu Brasil e Uruguai sobre o tema no Sistema de Solução de Controvérsias do Mercosul - ainda sob a vigência do Protocolo de Brasília -, a decisão do Tribunal Arbitral foi no sentido de que o Brasil não poderia impor qualquer restrição à importação de pneus usados provenientes do Uruguai sob pena de infringir norma de livre comércio do Mercosul; porém não chegou a apreciar a matéria sob a perspectiva ambiental já que este argumento não foi levantado pelo Brasil na época. 
A decisão preliminar do painel da OMC foi desfavorável ao Brasil: condenou a proibição de importar pneus usados e reformados, por violar regras comerciais internacionais. Entretanto, o Painel deixou claro que não questionou o direito de o Brasil implementar barreiras comerciais por razões ambientais, muito embora o governo brasileiro não tenha conseguido provar que a atual aplicação da barreira cumpre este objetivo, o de preservar o meio ambiente.

Interessante na sua decisão final é que o Painel acabou acatando as alegações do Brasil acerca da necessidade da proibição das importações de pneus usados e reformados procedentes da Europa. Para tanto considerou procedente a argumentação do Brasil de que esses pneus têm vida útil menor que os novos e que sua importação acelera a geração e o acúmulo de resíduos prejudiciais ao meio ambiente e à saúde pública. ${ }^{38}$ Desse modo ficou claro que a decisão dos árbitros da OMC foi motivada, sobretudo, por argumentos ambientais e de saúde pública.

A importância da decisão destaca-se por não haver até então significativos precedentes. Nesse sentido, cumpre enfatizar que se trata da primeira decisão contundente da OMC a reconhecer a legitimidade da proibição da importação de produtos potencialmente lesivos à saúde pública e ao meio ambiente.

Observe-se, que, apesar de confirmar a proibição à importação de pneus usados e reformados da União Européia para o Brasil, o Painel permitiu que o mercado brasileiro continuasse recebendo pneus remoldados de seus sócios do Mercosul, pois essa exceção não constituiria uma discriminação arbitrária ou injustificada contra produtos provenientes de outros países nem uma restrição disfarçada ao comércio internacional, tendo em vista a relação regionalista (Mercosul), que se encontra atualmente no estágio de União Aduaneira Incompleta, e sopesando o fato de as quantidades envolvidas serem insignificantes no comércio desse produto na região já que, comparativamente com as importações provenientes da Europa, as importações de pneus remoldados do Mercosul são mínimas e razoavelmente aceitáveis.

Frise-se todavia que, apesar de o relatório do Painel da OMC decidir que o Brasil poderia manter a proibição de importação de pneus usados e reformados originários da UE, esse também foi taxativo ao determinar que o Brasil deveria garantir de maneira eficaz a proibição da importação desses produtos de forma que cessassem

38 Segundo o Resumo Executivo da Segunda Petição do Brasil Perante a OMC: "O Brasil demonstrou que a proibição de importações é necessária para reduzir o acúmulo de resíduos de pneus e os riscos associados. As alternativas sugeridas pela UE não permitirão ao Brasil atingir o seu nível elegido de proteção, que é reduzir os riscos provocados por resíduos na máxima medida possível". 
as liminares que vinham sendo concedidas pelo Judiciário brasileiro aos importadores deste produto. ${ }^{39}$

Com efeito, no dia 3 de setembro, a UE apelou da decisão do Painel da OMC. Em sua decisão final, proferida no dia 3 de dezembro de 2007, o órgão de Apelação reverteu algumas decisões do Painel na disputa dos pneus entre Brasil e União Européia, com impacto no Mercosul e nas indústrias de pneus reformados. Em suma, o Órgão de Apelação da OMC confirmou a determinação central do Painel, reconhecendo que a proibição de importação de pneus reformados adotada pelo Brasil é justificável em razão da necessária proteção à saúde humana e o meio ambiente. Todavia, os árbitros reconheceram que o Brasil aplica tal medida restritiva de maneira discriminatória, na medida em que permite a importação de pneus reformados do Uruguai e do Paraguai. Nesse sentido desconsiderou tanto os argumentos da relação comunitária, como o das quantidades envolvidas. Destarte, exige a OMC que, para que seu direito de impor barreira não tarifária ambiental seja legítimo, o país feche as portas para todo tipo de importação de pneus usados ou reformados, independentemente de sua origem, pois, caso contrário, a medida deixaria de ser considerada legítima, conforme alegado pelo Brasil, para se configurar uma discriminação injustificável.

39 A esse respeito, o Presidente da República do Brasil ajuizou no STF argüição de descumprimento de preceito fundamental (ADPF 101) em que se discute as autorizações para importação de pneus usados e reformados, concedidas pelo Poder Judiciário brasileiro, em ofensa aos artigos 196 e 225 da CF (“Art. 196. A saúde é direito de todos e dever do Estado, garantido mediante políticas sociais e econômicas que visem à redução do risco de doença e de outros agravos e ao acesso universal e igualitário às ações e serviços para sua promoção, proteção e recuperação.(...) Art. 225. Todos têm direito ao meio ambiente ecologicamente equilibrado, bem de uso comum do povo e essencial à sadia qualidade de vida, impondo-se ao Poder Público e à coletividade o dever de defendê-lo e preservá-lo para as presentes e futuras gerações.”); além de afrontar Portarias do Departamento de Operações de Comércio Exterior - DECEX e da Secretaria de Comércio Exterior - SECEX, Resoluções do Conselho Nacional do Meio Ambiente - CONAMA e Decretos federais que, expressamente, vedam a importação de bens de consumo usados, com especial referência aos pneus usados. No mérito, a Min. Cármen Lúcia, relatora, julgou parcialmente procedente o pedido formulado para: 1) declarar válidas constitucionalmente as normas do art. 27 da Portaria DECEX 8/91; do Decreto 875/93, que ratificou a Convenção da Basiléia; do art. $4^{\circ}$ da Resolução 23/96; do art. $1^{\circ}$ da Resolução CONAMA 235/98; do art. $1^{\circ}$ da Portaria SECEX 8/2000; do art. $1^{\circ}$ da Portaria SECEX 2/2002; do art. 47-A do Decreto 3.179/99 e seu \2 $2^{\circ}$, incluído pelo Decreto 4.592/2003; do art. 39 da Portaria SECEX 17/2003; e do art. 40 da Portaria SECEX 14/2004, com efeitos ex tunc; 2) declarar inconstitucionais, também com efeitos ex tunc, as interpretações, incluídas as judicialmente acolhidas, que, afastando a aplicação daquelas normas, permitiram ou permitem a importação de pneus usados de qualquer espécie, aí incluídos os remoldados, ressalvados, quanto a estes, os provenientes dos Países integrantes do MERCOSUL, na forma das normas acima citadas e que tenham incidido sobre os casos; 3) excluir da incidência daqueles efeitos pretéritos determinados as decisões judiciais com trânsito em julgado, que não estejam sendo objeto de nenhum questionamento, uma vez que somente podem ser objeto da ADPF atos ou decisões normativas, administrativas ou judiciais impugnáveis judicialmente. 
Nesse cenário, a OMC acatou o argumento de tratamento discriminatório por parte do Brasil caso não cessassem as importações de pneus remoldados provenientes do Mercosul, assim como de outros países, obtidos por liminares. ${ }^{40} \mathrm{Tal}$ decisão baseia-se no entendimento de que, autorizando as importações do Mercosul, privilegiar-se-ia uma contradição, tendo em vista que a proteção da vida e da saúde não exclui as importações de pneus reformados dos países membros do Mercosul. nem tampouco a de pneus usados para reforma, autorizadas por liminares segundo a referida decisão autorizar a restrição à importação apenas da União Européia seria ratificar um tratamento discriminatório e injustificado, segundo as normas da OMC.

Resumidamente, pela decisão final da OMC, o Brasil não pode proibir a importação de pneus reformados da União Européia enquanto permite tal importação dos países membros do Mercosul nem tampouco continuar com as importações de pneus usados para reforma de outros países, enquanto mantiver a proibição de importação de pneus reformados.

\subsubsection{Mercosul: relações intrabloco e com terceiros países}

O Mercosul é um bloco econômico regional em processo de integração. Atualmente é classificado como União Aduaneira Incompleta por falta de alguns requisitos de integração regional como: (i) uma Tarifa Externa Comum para qualquer tipo de importação, (ii) adoção de uma política comercial externa comum, (iii) coordenação de políticas macroeconômicas e setoriais e, por fim, (iv) harmonização das legislações internas de seus Estados-Membros.

Superar todos esses obstáculos constitui apenas parte do lento processo para que o Mercosul possa aprofundar o nível de integração do bloco - a exemplo da União Européia. Ademais, é determinação constituinte brasileira que a América Latina seja mais do que um bloco econômico: seja efetivamente uma comunidade de nações, conforme prescreve o art. $4^{\circ}$., parágrafo único, CF do Brasil, in verbis: "A República Federativa do Brasil buscará a integração econômica, política, social e cultural dos povos da América Latina, visando à formação de uma comunidade latino-americana de nações".

Diante desse quadro, há que considerar que as regras e decisões estabelecidas no Mercosul têm por fundamento um compromisso maior do que unicamente o livre comércio, tendo em vista que a integração no Cone Sul busca mais do que o fortalecimento das relações comerciais, mas a criação de uma comunidade de nações na região.

$\overline{40}$ Cf. ADPF 101. <www.stf.gov.br>. De um lado, o governo brasileiro tenta acelerar a obtenção no STF de uma decisão definitiva para pôr fim às liminares obtidas na Justiça que permitem importações de pneus usados e reformados. De outro, negocia com o Paraguai e Uruguai para estabelecer um regime comum de tratamento de pneus usados e reformados no bloco. 
Destarte, os compromissos e acordos feitos pelos países membros do Mercosul diferenciam-se daqueles realizados por cada Estado-Parte do Mercosul e terceiros países, justamente porque as relações comerciais com países não membros do bloco baseiam-se unicamente nas regras e princípios de direito internacional ratificados pelos Estados envolvidos e não por princípios maiores de integração e fortalecimento macroeconômico como em tese acontece no Mercosul.

Desta perspectiva, pode-se dizer em princípio não caracterizaria tratamento discriminatório do comércio internacional a proibição de importação de pneus usados e reformados da União Européia, mesmo diante das importações de pneus remoldados procedentes do Uruguai, haja vista o Brasil aplicar o princípio solidário das obrigações comuns, porém diferenciadas. Em outras palavras, o Brasil estaria autorizado a dar tratamento privilegiado aos sócios menos desenvolvidos do Mercosul em nome do direito ao desenvolvimento destes, sem que isso afetasse o princípio do tratamento nacional, por se tratar do reconhecimento ao princípio da solidariedade que se concretiza, no caso, por intermédio das obrigações comuns, porém diferenciadas. Isso é, todos devem preservar o meio ambiente saudável, mas os níveis de proteção exigidos pelos países são diferentes em razão do estágio de desenvolvimento de cada um. Note-se que, no caso em tela, (1) a participação num sistema regional (2) o atual estágio de desenvolvimento do Uruguai e (3) o volume de exportação justificam um tratamento diferenciado.

Não se pode afirmar ao certo, mas se acredita que foi com esse pensamento que o Painel da OMC decidiu pela procedência das alegações do Brasil no sentido de continuar com as importações de pneus remoldados dos países membros do Mercosul. Todavia, o Órgão de Apelação da OMC, apesar de manter o mesmo entendimento de que é aplicável ao caso a exceção ambiental como medida de tutela da vida e da saúde das pessoas animais e vegetais, reprovou a conduta do Brasil de tratar diferentemente o país vizinho pouco desenvolvido e autorizar a entrada em seu território de bem considerado danoso ao meio ambiente em nome dos objetivos do bloco e dentro do prisma solidário, ou ainda porque as quantidades envolvidas não seriam significativas. Com efeito, o Órgão de Apelação entendeu que tais argumentos são insatisfatórios e injustificáveis diante de uma visão mais focada na liberdade do que na solidariedade. Assim, foi reformada a decisão do Painel com fundamento no princípio da não discriminação, pilar do princípio do tratamento nacional por nós estudado no início do trabalho.

Nesse contexto, da ótica do princípio do tratamento nacional e sua perspectiva de não discriminação entre os países membros da OMC, injustificável seria a procedência da decisão do Painel e a validade de seu respectivo raciocínio. Entretanto, em razão da exceção ambiental de proteção da vida e da saúde das pessoas, animais 
e vegetais, não há como contestar a coerência da decisão do Painel. Nessa linha, o Órgão de Apelação confirmou a aplicabilidade da exceção ambiental ao caso, mas reformou a decisão do Painel no tocante à autorização para importação de pneus reformados entre os países do Mercosul, assim como de pneus usados para reforma, privilegiando com isso o princípio do tratamento nacional em detrimento do argumento brasileiro acerca dos objetivos assumidos no Tratado de Assunção e considerando que o processo de integração deve levar em conta bens maiores como aqueles tutelados pelo direito ambiental ${ }^{41}$ além do processo dinamogênico dos Direitos Humanos.

Ocorre, todavia, conforme já foi mencionado, que os objetivos constitucionais brasileiros são muito mais amplos do que uma integração restrita à dimensão econômica. Além disso, no atual estágio de desenvolvimento dos direitos humanos, no qual se reconhece o direito ao desenvolvimento dos Estados, assim como dos indivíduos, não há como desconsiderar o argumento apresentado pelo Brasil, mesmo porque a preocupação com o aumento da importação de pneus dos países do Mercosul implicaria uma transformação do status de medida, ou seja, de justificável para injustificável. Mas a insistência do tratamento igualitário apenas formalmente e sem nenhuma ponderação ou calibragem do estágio de desenvolvimento, viola atuais e elementares noções e princípios de direito, inclusive internacional. Portanto, parece nos equivocada a decisão do Órgão de Apelação que ${ }^{42}$ deixou de considerar aspectos muito relevantes e fundamentais nas relações comerciais, que não mais podem ser tratados isoladamente.

Por derradeiro, cumpre salientar que a nosso ver não há conflito jurídico entre a decisão da OMC e a do Tribunal de Revisão do Mercosul, posto que, conforme acima estudado, este não apreciou a questão ambiental quando decidiu o conflito entre Brasil e Uruguai no caso dos pneus. De qualquer forma, em eventual caso de conflito entre uma decisão do Mercosul e da OMC, há que se considerar que esta organização internacional tem mais força política que qualquer decisão proferida por órgão regional que afete diretamente o comércio internacional, diante do poder de retaliação dos seus Estados-Membros. ${ }^{43}$ Entretanto, entende-se que não há como

$\overline{41}$ Nesse sentido, há uma razoável preocupação, inclusive do Ministério do Meio Ambiente brasileiro, de que o Uruguai e o Paraguai passem a ser utilizados como "barrigas de aluguel" para pneus reformados da Europa e de outros países, destinados ao Brasil, o que autorizaria o Brasil, em nome do princípio da boa-fé, impor restrições à importação de pneus dos países vizinhos.

42 Observe neste sentido os fundamentos das chamadas obrigações comuns, porém diferenciados, de uma série de tratados.

43 A decisão do Órgão de Apelação da OMC, de que o Brasil deveria adequar-se internamente para impedir que o país continuasse autorizando a importação de pneus reformados - o que vinha ocorrendo por meio de liminares - tinha prazo até 17 de dezembro de 2008 para ser efetivada, sob pena de retaliação pela UE. Antes disso, o Brasil fechou um acordo com a UE 
sustentar qualquer tipo de hierarquia entre essas instâncias, mesmo porque o caso em análise, assim como outros, demonstra a grande quantidade de detalhes que juridicamente possa sustentar tal posição.

\section{Considerações Finais}

Este trabalho buscou apresentar, por intermédio da dogmática internacional e da perspectiva atual da solidariedade, a relação entre comércio internacional e meio ambiente além de outros a ele correlatos como: (i) barreira não tarifária ambiental; (ii) dumping ecológico; (ii) discriminação (in)justificada entre produtos nacionais e importados similares; (iv) tratamento discriminatório entre países membros da OMC; (v) política de cooperação internacional de proteção ao meio ambiente; (vi) direitos humanos e (vii) desenvolvimento sustentável.

Pudemos perceber ao longo dessa reflexão que a Organização Mundial do Comércio há tempo se preocupa com a proteção ao meio ambiente, prevendo inclusive a possibilidade de restrição ao livre comércio por intermédio de barreira não tarifária ambiental, desde que justificadamente necessária a adoção dessa medida.

Nesse compasso, o Órgão de Solução de Controvérsias da OMC tem entendido ser plenamente aplicável a exceção ambiental desde que tal medida não caracterize discriminação injustificada do comércio internacional.

No primeiro caso analisado - o caso da gasolina, acionado pela Venezuela e Brasil contra os EUA - o OSC da OMC entendeu pela desnecessidade de aplicação da restrição ambiental, principalmente diante da discriminação feita entre o produto nacional e o similar importado, pois tal medida caracterizava, na verdade, tratamento discriminatório injustificado e uma restrição disfarçada ao comércio internacional.

Já no segundo caso estudado, o caso da proibição de importação de pneumáticos reformados provenientes da União Européia, entendeu o OSC da OMC que a medida adotada pelo Brasil é plenamente justificável por não haver atualmente medida adequada de disposição final das carcaças usadas, o que acaba gerando acúmulo de lixo ou, pior, a emissão de gases tóxicos no meio ambiente, prejudicando, de uma forma ou de outra, a vida e a saúde das pessoas, animais e vegetais. Entretanto,

para uniformizar a proibição à importação de pneus reformados (o Brasil proíbe a importação de pneus usados e reformados, mas apenas a proibição dos reformados foi contestada para UE). Com o referido acordo, a UE abre mão de deflagrar a demanda agora, mas não perde esse direito, persistindo a ameaça de sanção contra o Brasil enquanto perdurar a proibição da entrada de pneu reformado europeu, mas não a mesma proibição aos países membros do Mercosul. 
no referido caso, se exigiu do Brasil que a proibição de importação de pneus reformados se estenda aos pneus reformados provenientes dos países membros do Mercosul sob pena da medida ambiental brasileira caracterizar tratamento discriminatório injustificado entre países membros da OMC. Da mesma forma, exigiu a OMC que tal medida seja efetiva, eliminando-se, assim, as liminares autorizadoras dessas importações, independente da origem. No que pese a importância da decisão, principalmente em relação ao histórico/jurisprudência do órgão, este deixou de considerar o direito ao desenvolvimento dos Estados e suas consequências no atual paradigma da solidariedade.

Do exposto, restou claro que todo Estado tem o direito soberano de impor seus próprios níveis de proteção, desde que não discriminatória e justificada. Contudo lado, acredita-se que os organismos internacionais e principalmente a OMC devem pautar-se na atual perspectiva da solidariedade e do direito ao desenvolvimento na análise de suas decisões.

Assim, é possível concluir que, no caso da gasolina, privilegiou-se o princípio do tratamento nacional, uma vez que a barreira não tarifária ambiental americana era injustificada. Já no caso dos pneus privilegiou-se o meio ambiente por ser a proibição de importação de pneus, uma barreira não tarifária ambiental absolutamente legítima, uma vez que as carcaças causam, efetivamente, graves danos ao meio ambiente, colocando em risco a vida e a saúde das pessoas, animais e vegetais. Todavia, perdeu-se a oportunidade de uma reflexão jurídica mais complexa e atual sob o paradigma difuso da solidariedade e do reconhecimento do direito ao desenvolvimento dos Estados.

Acredita-se que cada vez mais o OSC da OMC e outros órgãos e tribunais internacionais deverão se debruçar sobre a relação entre comércio internacional e meio ambiente, dando ênfase ao meio ambiente em questões comerciais quando a medida for justificável. Todavia, forçoso ressaltar que não basta uma boa solução de controvérsia, resguardando-se os princípios que compatibilizam o comércio e o meio ambiente. Necessária se faz, também, a adoção de uma política internacional de conscientização ambiental, transferência de tecnologia e investimento financeiro, dando-se concretude e eficácia ao direito ao desenvolvimento dos Estados e indivíduos. Observa-se que tais medidas são capazes de gerar o menor impacto possível ao meio ambiente, conduta esta que deve ser estimulada por políticas públicas nacionais e internacionais, vez que somente assim haverá uma verdadeira integração entre comércio e meio ambiente, preservando-se as presentes e as futuras gerações por intermédio de um desenvolvimento sustentável. 


\section{Referências Bibliográficas}

BRASIL. Poder Executivo. Ministério do Desenvolvimento, Indústria e Comércio Exterior (Secretaria de Comércio Exterior) e Confederação Nacional da Indústria. Barreiras externas às exportações brasileiras para os Estados Unidos, Japão e União Européia 2001. Brasília: CNI, 2001.

GUERRA FILHO, Willis Santiago. Processo constitucional e direitos fundamentais. 4 ed. São Paulo: RCS, 2005.

KISS, Alexandre. Droit international de l'environnement. Paris: Editions A. Pedone, 1989.

PROCÓPIO FILHO; VAZ; TACHINARDI, M. H. Ecoprotecionismo: comércio internacional, agricultura e meio ambiente. Brasília: IPEA, 1994, p. 10.

YOUNG, Carlos E. F.; LUSTOSA, Maria C. J. Meio ambiental e competitividade na indústria brasileira. Revista de Economia Contemporânea, Instituto de Economia - UFRJ, v. 5, n. especial, ano 2003.

\section{Site}

ALVES, Flávia. As barreiras técnicas e os PPMs. Disponível em: <www.eclac.org/dmaah/noticias/ paginas/9/28579/BTsePPMs.pdf >. Acesso em: 02 nov. 2007.

BLANK, Dionis Mauri Penning; BRAUNER, Maria Cláudia Crespo. A responsabilidade civil ambiental das instituições bancárias pelo risco ambiental produzido por empresas financiadas. Disponível em: <http://www.remea.furg.br/edicoes/vol22/art19v22.pdf>. Acesso em: 28 ago. 2009.

CHO, S. Gasoline: United States - standards for reformulated and conventional gasoline. E.J.I.L., 1, 9:163, 1998. Disponível em: <http://www.ejil.org/journal/Vol9/No1/sr1a.html>. Acesso em: 12 fev. 2007.

SILVA, Henry Yure de Paiva. Interação entre comércio e meio ambiente. Disponível em: <http://www.ccj. ufpb.br/primafacie/prima/artigos/n6/interacao.pdf.> Acesso em: 10 nov. 2007.

VIANA, Maurício Boratto. O meio ambiente no Mercosul. Consultoria legislativa: estudo maio/2004. Disponível em: <www.uvb.com.br.> Acesso em: 23 jun. 2008.

WOLFF, Simone. Meio ambiente X desenvolvimento + solidariedade = humanidade. Disponível em: $<$ http: / / planalto.gov.br/ccivil_03/revista/Rev_67/artigos/Art_Simone.htm>. Acesso em: 27 ago. 2008.

$<$ www.mre.gov.br>. Acesso em: 03 ago. 2007.

$<$ www.uvb.com.br>. 